REGULAR ARTICLE

\title{
FOOD PRODUCTION AND CONSUMPTION IN THE HIGHLANDS OF ETHIOPIA: THE MISSING LINK IN FOOD SYSTEMS
}

\author{
Wuletaw MEKURIA ${ }^{l}$ (D), Kindu MEKONNEN ${ }^{2}$, Taye MELESE ${ }^{1 *}$ (D)
}

\begin{abstract}
Address:
${ }^{1}$ College of Agriculture and Environmental Sciences, University of Gondar P.O. Box 196, Gondar, Ethiopia

${ }^{2}$ Crop-livestock Scientist, International Livestock Research Institute (ILRI), P.O. Box 5689, Addis Ababa, Ethiopia

* Corresponding author: tayemelese20@mail.com
\end{abstract}

\begin{abstract}
This paper attempted the nexus of food production and consumption, and determinants of food consumption in Gudo Beret watershed, central highlands of Ethiopia. The study used cross-sectional data collected from 211 randomly selected households through interview. Descriptive statistics and linear regression were the key analytical techniques. Results revealed that households produced a gross yield of 1.5 ton and a net food supply of 1.1 ton per household which was equivalent to $274 \mathrm{~kg}$ of grain per adult per annum. The average food demand per capita was $323.8 \mathrm{~kg}$ per adult. It implies food production was inadequate for food consumption. Sex of household head being male, livestock holding, inorganic fertilizer, total land size, and market distance affected household food consumption positively whereas household size had negative impacts on household food energy. One of the current themes of the food systems is balancing food production and consumption. The government of Ethiopia should deliberate population policy with the intention that the rising population need to have adequate subsistence. In addition, women empowerment can enable them access to and control over food resources.
\end{abstract}

Keywords: Crop production, food energy, grains, Ethiopia, households JEL: R52, R58, H41

\section{INTRODUCTION}

Food system is a wide range of activities that makes certain food production reaches consumers (Burrows and Kuyper, 2018). The main function of food system is food production (FAO, 2017). At household level, the key characteristic of food system is seed exchange despite local seeds are attributable to low yields, lack of quality, mixed varieties and loss of desirable traits (Asante et al.,2017). Access to improved crop varieties is critical to food and nutrition security (Toledo and Burlingame, 2017). Farm households grow more than one variety of a given crop at a time for which no single variety would satisfy their livelihood demands. Varietal selection and farm management are the most crucial actions in agricultural production and genetic conservation. Agricultural production is the main pathway that impacts human nutrition. Globally, there has been a contemporary interest in food and nutrition security to decelerate malnutrition. Much of this interest is focused on sustainable agriculture to produce adequate food for the growing population. Agriculture contributes for $34 \%$ of gross domestic product, $80 \%$ of export earnings, and $80 \%$ of employment opportunities in the Ethiopian economy (WB, 2013; NPC, 2016; Admasu, 2017). Farmers in the highlands of the country depend largely on mixed farming to improve dietary diversity, increase household income, reduce vulnerability to shocks, create job opportunity, minimizes risks and insurance against crop failures
(Liniger et al., 2016; Alexandratos and Bruinsma, 2012; Belay et al., 2012; Darnhofer et al., 2012; Herrero et al., 2012; Moraine et al., 2014). Mixed farming provides a wide range of responses to uncertain conditions and increase household resilience (Liniger et al., 2016; Kuria et al., 2014). In Ethiopia, nearly 14 million households cultivate about 15 million ha of land (CSA, 2015). The average productivity of major crops is $21.5 \mathrm{qt}$ per ha (FDRE, 2016). Crops are the major sources of food while animal products are often low (Belay $\boldsymbol{e t}$ al., 2012, CSA, 2012). Livestock generate more than $85 \%$ of cash income, $16 \%$ of export earnings (Yayneshet, 2016), and $25 \%$ of growth domestic product (FDRE, 2016). Households with large herd sizes have better chance to ensure household food security (Messay, 2010; Mesfin, 2014).

In Ethiopia, farm households have long experiences on varietal selection, adaptation and adoption of various crop varieties in the history of crop evolution. For instance, barley is one of the first domesticated cereals since 3000 B.C (FAO, 2008). Farmers are rational decision makers in the processes of production based on their existing knowledge (Olango et al., 2014) that aligned with the broader social and ecological landscapes where diverse landraces are maintained in the seed systems (Samberg et al., 2013). A particular crop serves for different purposes as barley grain is used for soup, stew, bread, biscuit, injera, and feed for honeybee colonies (Alemayehu, 2011). The supply of malt demand for 
breweries is $32.8 \%$ from domestic sources of barley while the remaining proportion has been imported from abroad. It implies the subsistence farming system could not supply an adequate level of malt for beer industries.

Crop yields are a function of climate variables, seed varieties, availability of water, soil nutrients, and knowledge of farmers (God fray, 2010). Favorable weather conditions of a year results in good harvest whereas severe droughts causes for crop failures that adversely affect agricultural production and consumption patterns. Despite apparent yield increment has been reported in Ethiopia (Alemayehu, 2011), the amount of growth is not overwhelming (Dercon and Hill, 2009; Mekuria et al., 2017). In the country, large number of people $(29.6 \%)$ is living below the poverty line (WFP, 2014) and significant number of people (35\%) is undernourished (FAO, 2018). On the one hand, pasturelands and the natural vegetation are converted to croplands and commercial investments in some parts of Ethiopia (Wily, 2011). On the other hand, lands allocated for cereals, coffee, fruit, root and vegetable crops are converted to Khat and eucalyptus plantation in many parts of the nation (Yeshaneh et al., 2013; Cochrane and O'Regan,2015; Daniel et al., 2016; Tadesse and Tafere, 2017). Moreover, there is no policy decree on social protection towards consumption insurance except productive safety net programs in some draught prone areas of the country (FAO, 2018).

Ethiopia is vulnerable to the twin threats of natural resource degradation and poverty owing to high population growth, soil loss, and negative impacts of climate changes (Liniger et al., 2016, WFP, 2014, Badege, 2009; Yitebitu et al., 2010; IFAD, 2013). Climate shock is one of the leading causes of food crisis situations that 8.5 million people were affected recently by climate shocks and conflict (FAO, 2018). Rapidly growing population is one of the key drivers for competitive demands between crop production and livestock husbandry (IFAD, 2010; Rota and Sperandini, 2010). One-third of rural households in Ethiopia could not produce adequate food to meet their subsistence needs as they cultivate less than half hectares of land per capita (Herrero et al., 2012). The existing agricultural land is unable to feed the growing population and thus many Ethiopians remain trapped in vicious circle of poverty, disease and hunger (Sahlu, 2004).Rising in food prices, unemployment, lack of pasture for livestock, and intensive removal of natural vegetation aggravates food shortages. Food and nutrition insecurity, low crop and livestock productivity, excessive land fragmentation, and severe land degradation are among persistent challenges in the highlands (NPC, 2016, Yeshaneh et al., 2013, IFAD, 2013, Demese et al., 2010; Haregeweyn et al., 2015; Hurni et al., 2016; Guush et al., 2017; Mekonnen et al., 2017). In the country, $14 \%, 9 \%$, and $25 \%$ of children are stunted, wasted and underweight, respectively (Birhanu, 2015). The negative impact of climate change exacerbate land degradation by increasing water stress, soil erosion, soil acidity, landslides, feed shortage, and increase the incidence of ani mal diseases (Liniger et al., 2016; Tongul and Hobson, 2013; Bewket, 2015).
Intensified farming and continuous cultivation with limited soil amendments and conservation practices resulted in soil erosion and nutrient depletion (IFAD, 2010). Low adoption of agricultural technologies and feed scarcity are still adversely affecting the livelihoods of farmers and landscape situations of the study area (Kuria et al, 2014, Mekonnen et al., 2017, Tigist, 2016; Tamene, 2017). Although research institutions have been developed new crop varieties, improved seeds do not reach farmers at all, or if they do, they get to them late. Lack of improved seed varieties affects both producers and consumers. The supply of raw materials alone could not able to keep with the increasing demands of domestic industries (Asante et al., 2017). Despite several researches have been conducted on food security and production efficiencies, studies on food systems in terms of production and consumption linkages is minimal. The assumption is that farm households may not consume what they produce due to several reasons. Therefore, the objectives of this paper are to examine the linkage of food production and consumption and to analyse determinants of food consumption in the study area. The next sections of the paper include materials and methods, results and discussion, and conclusion and policy implications.

\section{DATA AND METHODS}

\section{Description of the study area}

The study area is located in the highlands of Ethiopia. The site is found in Gudo Beret Kebele, Bsona Werana district, and North Shewa zone of Amhara region. (Kebele is the lowest geographical administrative unit). The total population size of the study was estimated to be 2070 inhabitants and the population density was about 85 persons per square kilometer. The total number of households in the study catchment was 447. Subsistence rain-fed cultivation, livestock husbandry, and woodlots were the dominant farm activities. The natural vegetation cover has declined over time due to anthropogenic factors. Currently, there is no natural forest except some shrubs and bushes at the upper escarpment of the watershed. Eucalyptus trees are grown around homesteads, hillsides, and gully buffers. A small town (Gudo Beret), the local market, Kebele agriculture office, human and animal health clinics, rural villages, churches, elementary schools, electricity power line, private mobile telephone, and asphalt road are the main infrastructures and institutions found in the study watershed. The study site is characterized by degraded lands above the tolerable soil erosion limits (Tamene, 2017).

\section{Sampling procedures}

The study watershed was purposively selected because of high crop-livestock production potential. The area was delineated starting from the bottom confluence point between the two streams (Feleku and Weynabchu) and reached the upper escarpment of the watershed. The top part of the dividing line of the study watershed is the boundary between the Blue Nile and Awash basins. A total sample size was determined according to Israel (1992) (Eq. 1). 
$n=\frac{N}{1+N(e)^{2}}=211$

Where: $n$ is the total sample size, $N$ is the size household in the study watershed, and $e$ is a confidence level taking 0.5 as an average level of precision in social science.

Among the total households, $29 \%$ were femaleheaded. The total sample size was selected using systematic random sampling. Four data collectors were employed and household survey was conducted in face-toface interview through house-to-house visits from end of May to the first week of July 2016. Training was conducted for enumerators on methods of data collection. The interview schedule was prepared by administering different socio-economic, institutional and climatic variables. The questions in the interview schedule were pretested before administering data collection.

\section{Methods of data collection}

The collected data were cross-sectional obtained from primary and secondary sources but were not limited to demographic attributes (sex, age, level of education, household size, and social status), economic factors (total land size, household income, crop varieties, livestock breeds, crop yields, consumptions), and bio-physical variables (settlement patterns, distance between households' residence and the local market and asphalt road). In-depth interviews were employed for purposively selected key informants to identify crop-livestock portfolios. Key informants include local level officials, elders, and agricultural experts. Household interviews were conducted using a semi-structured interview schedule. The primary data were collected from selected respondents during household survey. Questions in the interview schedule were pre-tested prior to conducting the formal survey and essential amendments were made on the interview schedule. Training on methods of data collection was employed for enumerators how to collect primary data. All information contained in the interviews was confidential. Personal observation was employed to triangulate landscape situations, settlement patterns, accessibility of infrastructures and institutions as well.

\section{Methods of data analysis}

Data processing such as coding, editing, cleaning, verification, and entry were employed prior to data analysis. Depending on the nature of data, descriptive statistics (frequency, percentage, and mean) and inferential tests were employed. Descriptive statistics were mainly employed to compute the food produced and consumed in the study area. Household food balance model was employed to compute the food expenditure and net food supply for household consumption. Consequently, the net available food was converted to food calorie per capita at household level. First, each food item was computed in terms of quintal or ton and then converted to $\mathrm{kg}$ ( 1 ton $=10 \mathrm{qt}=1000 \mathrm{~kg}$ ). Secondly, food items measured in $\mathrm{kg}$ was converted to food calories after multiplying by each conversion factor that was given for each food items. The conversion factors from $\mathrm{kg}$ to calories are shown in the Table 1 .
Table 1: Conversion factors for per capita calorie consumptions

\begin{tabular}{|c|c|c|c|}
\hline $\begin{array}{l}\text { Available } \\
\text { food items }\end{array}$ & $\begin{array}{l}\text { Conversion } \\
\text { factors }\end{array}$ & $\begin{array}{l}\text { Available } \\
\text { food items }\end{array}$ & $\begin{array}{l}\text { Conversion } \\
\text { factors }\end{array}$ \\
\hline Food barley & 3320 & $\begin{array}{l}\text { Green } \\
\text { vegetables }\end{array}$ & 220 \\
\hline Malt Barley & 3680 & Apple fruit & 480 \\
\hline Wheat & 3340 & Sheep meat & 1230 \\
\hline Faba bean & 3420 & $\begin{array}{l}\text { Chicken } \\
\text { eggs }\end{array}$ & 1390 \\
\hline Field pea & 3460 & Cow milk & 610 \\
\hline Lentil & 3460 & Butter & 7170 \\
\hline Linseed & 4980 & Honey & 2980 \\
\hline Potato & 670 & & \\
\hline
\end{tabular}

Source: EHNRI (1998)

Linear regression was employed to examine determinants of food consumption. According to FAO $\boldsymbol{e t}$ al. (2018), food availability is the dietary energy supply expressed in terms of $\mathrm{kcal} / \mathrm{person} / \mathrm{day}$. An average food calorie per $\mathrm{AE}$ per day was taken as a continuous dependent variable while thirteen independent variables were considered for analysis (Table 2). The linear regression, ordinary least square (OLS) was adapted in Gujarati (Gujarati, 2003) (Eq. 2).

$Y_{i}=X^{\prime} \beta_{i}+U_{i}$

Where; $Y_{i}$ is a continuous dependent variable; $\beta_{i}$ are parameters; $X_{i}$ are independent variables; $U_{i}$ is error terms.

\section{RESULTS AND DISCUSSION}

\section{Household characteristics}

The proportion of female-headed households was $29 \%$. The size of illiterate household heads was $20.9 \%$. About $42.7 \%$ of household heads had basic educational levels. Grade $1-4$ and 5-8 were $15.2 \%$ and $16.1 \%$, respectively while grade 9 and above were $5.2 \%$. The minimum age of household heads was 23 while the maximum age was 82 years old. In the study area, the mean age of household heads was 43.8 years old. The minimum and maximum household sizes were 1 and 10 while the average size of household members and labour force were 4.5 and 2.9, respectively. The average land size was 1.3 ha per household whereas the average livestock holding was 4.0 TLUs per household.

\section{Agricultural production in the study area}

In the study watershed, crop production, animal husbandry, and eucalyptus plantation were the major livelihood strategies for rural households. There is interhousehold heterogeneity for choice of crops and livestock activities. Limited number of households (5.6\%) could not access land use rights and they were dependent on their livestock holdings and non-farm/off-farm activities, while $8 \%$ of households did not own livestock. Cattle, equines, sheep, goats, and chicken are the major livestock types in the study area (Table 3). 
Table 2: Hypothesis of independent variables in relation to household food consumption

\begin{tabular}{|c|c|c|c|}
\hline Acronyms & Explanations & Units and measurements & Hypothesis \\
\hline AGE & Age of household head & A continuous variable measured in years & - \\
\hline HHSIZE & Household size & $\begin{array}{l}\text { A continuous variable measured in number of } \\
\text { household members }\end{array}$ & - \\
\hline SEX & Sex of household head & It is a dummy variable, $1=$ male and 0 otherwise & $+($ male $)$ \\
\hline EDUC & $\begin{array}{l}\text { Educational level of } \\
\text { household head }\end{array}$ & $\begin{array}{l}\text { It is a continuous variable measured in years of } \\
\text { schooling }\end{array}$ & + \\
\hline INCOME & Household income & It is a continuous variable in ETB & + \\
\hline LAND & Total land size & It is a continuous variable measured in ha & + \\
\hline MANURE & Compost used & It is a continuous variable measure in $\mathrm{kg}$ & + \\
\hline LIVES & Livestock holding size & It is a continuous variable measured in TLU & + \\
\hline FERT & Fertilizer applied & It is a continuous variable measured in $\mathrm{kg}$ & + \\
\hline DMKT & Market distance & $\begin{array}{l}\text { A distance between the local market and } \\
\text { household's residence measured in walking } \\
\text { minutes }\end{array}$ & - \\
\hline DROAD & Road distance & $\begin{array}{l}\text { A distance between the main asphalt road and } \\
\text { household's residence measured in walking } \\
\text { minutes }\end{array}$ & - \\
\hline EXTEN & Extension contact & $\begin{array}{l}\text { Extension contact is the frequency of contact of } \\
\text { DAs with household head in per month }\end{array}$ & + \\
\hline CREDIT & Access to credit service & $\begin{array}{l}\text { It is a dummy variable, } 1=\text { access to credit, } 0 \\
\text { otherwise }\end{array}$ & + \\
\hline
\end{tabular}

Table 3: Livestock production by sampled households (2016)

\begin{tabular}{lrrr}
\hline Types of livestock & Number & TLU & Proportion (\%) \\
\hline Cow & 151 & 121 & 3 \\
Ox & 288 & 317 & 15 \\
Heifer & 53 & 26 & 38 \\
Bull & 50 & 30 & 38 \\
Calf & 109 & 22 & 59 \\
Horse & 35 & 28 & 5 \\
Mule & 4 & 3 & 50 \\
Donkey & 246 & 123 & 25 \\
Sheep & 1532 & 153 & 22 \\
Goat & 115 & 12 & 10 \\
Chicken & 744 & 7 & 52 \\
Total & 3327 & 841 & 28 \\
\hline
\end{tabular}

Livestock contribute for food, wool, draught power, transportation, manure, hide and skin, fuel, and sociocultural services such as wedding, dewy, festivities, holidays, and rituals. However, the productivity of livestock per animal such as milk, meat, and egg were relatively low. Sheep and goat accounted for $20 \%$ while donkeys represented $15 \%$ of the total livestock population in terms of TLU. The highest proportion of cattle was for oxen $(38 \%)$ followed by cows $(14 \%)$. The remaining stock (bull, heifer, calf, horse, mule) accounted only $13 \%$. The majority of livestock populations $(61 \%)$ were cattle followed by sheep and goat (20\%), equine (18\%) and chicken $(1 \%)$, respectively. About, $60.2 \%$ of households owned cows. The sizes of local and crossbred cows were 1.21 and 1.15 per household respectively, 1.19 on average. Households produced on average $15 \mathrm{~kg}$ of eggs, $2280 \mathrm{~kg}$ of meat, and $105 \mathrm{~kg}$ of milk per year, respectively.

Most recently, animals were prioritized based on land preparations for cultivation purposes and immediate benefits compared to purposes of rearing for permanent household assets. In this regard, households rear livestock for farming operations and selling purposes than keeping them for long-term asset accumulation. According to key informants, the reasons for increment of livestock population were rising demand for household food consumption, market price incentives and increasing number of households. The size of dairy cows was $23.4 \%$ of the total cattle population, which is higher than the national average-14.6\% (Aleme and Lemma, 2015). Three-quarters $(75 \%)$ of the cattle population were indigenous breeds while $25 \%$ were improved breeds. In terms of livestock number, oxen were the highest cattle population while sheep were the highest in livestock population. Sheep and chicken were the largest livestock population in number followed by oxen, donkeys and cows. In the study area, sheep production was the most common practice due to the fact that agro-climates in highlands is suitable for sheep production so that households rear them mainly for selling to earn household incomes.

Almost every household produced annual crops. Among the five major cereals (tef, wheat, maize, sorghum, and barley), barley and wheat were the predominant (50\%) crops grown in the study area. Faba bean, field pea and lentil were the three major pulse crops grown in the study watershed. Households also produced vegetables, Irish potato, oats and linseed on small plots of land. The majority (96\%) of households produce food barley followed by faba bean, field pea and wheat. Food barley, faba bean, and wheat were the three most important crops produced in the study area (Table 4). Households produced 1.7 ton of crops per capita annually. The average crop productivity was 1.34 ton per ha while the total cropland size of households was 1.2 ha. 
Table 4: Crops produced by sample households (2015/16)

\begin{tabular}{lrrrr}
\hline Crops & $\begin{array}{l}\text { Farmers } \\
(\%)\end{array}$ & $\begin{array}{l}\text { Land } \\
\text { (ha) }\end{array}$ & $\begin{array}{l}\text { size } \\
\text { Total } \\
\text { production } \\
\text { Ton }\end{array}$ & $\%$ \\
\hline Barley & 105 & 100 & 174 & 50 \\
Wheat & 55 & 30 & 46 & 13 \\
Faba bean & 85 & 54 & 68 & 19 \\
Field pea & 66 & 43 & 31 & 9 \\
Lentil & 7 & 11 & 2 & 1 \\
Linseed & 10 & 3 & 1 & 0 \\
Irish potato & 19 & 7 & 25 & 7 \\
Vegetables & 15 & 12 & 1 & 0 \\
Total & & 260 & 349 & \\
\hline
\end{tabular}

\section{Household food consumption}

According to the balance sheet model, the net food supply is the difference between food resources obtained from various sources and food expenditure. Households produced various crops and livestock for different purposes. The yield they produced went to various economic, social and cultural obligations. Locally grown crops and livestock resources were the major sources of food products. Market and social transfers were supplementary food sources. Food items in dietary diversity could be more than 46 types (Gujarati, 2003). In the study watershed, households produced fifteen types of food crops. In this paper, food consumption refers to net food supply in terms of calories. According to Kearney (2010) food consumption is synonymous with food availability. The annual consumptions of animal products were estimated to be 8,22 , and $75 \mathrm{~kg}$ of egg, meat, and milk per household, respectively. The most important meat sources were sheep, goat, chicken, ox, and cow. Several studies overlooked food items obtained from animal products. In this study, the contribution of animal products for food consumptions was only $10 \%$. Almost $90 \%$ of the food sources were crops (Table 5). Household consumed $71.5 \%$ of staple foods and $32.9 \%$ of leafy vegetables and potato. Lentil, barley and wheat were the major source of food for home consumption. Households consumed fewer amounts of linseed, pea and staple crops. The majority of butter (87.5\%), honey (75.4\%), and eggs $(50.8 \%)$ went to market for cash income which were not used for food consumption

The food balance sheet model indicated different food sources, food expenditures and net food supply. Food demand was calculated in accordance with major demographic variables such as sex and age of each household member. Conversion factors for children vary between 0.29 and 0.79 adult equivalent depending on their ages, for women ranges between 0.75 and 0.86 while for men it ranges between 0.98 and 1.18 (Claro, et al., 2010). Despite the minimum and maximum amount of food demand is 357 and $536 \mathrm{~kg}$ per adult per year is required at global level (WHO, 2004), the average grain food consumption demand per capita is $323.8 \mathrm{~kg}$ in Ethiopia (Guush et al., 2017). In this study, for 844 adults, the annual food supply was estimated $274 \mathrm{~kg}$ of grain per adult, which was equivalent to a gross yield of 1.5 ton and a net food supply of 1.1 ton per household. Based on the actual grain yield supply estimation, sample households need an extra 42 ton of grain or $6.7 \%$ additional cropland to raise the grain supply to achieve 0.3 ton per capita. Some households purchased food crops both for home consumption and seed resources. The sources for the majority of food consumption were from their own production. Households spent about $70 \%$ of the food for own consumption and the remaining $30 \%$ went to different expenditures such as selling, social transfer, postharvest loss, and seed reserves.

Table 5: Food balance sheet model for sample households (2015/16)

\begin{tabular}{|c|c|c|c|c|c|c|c|c|c|c|c|}
\hline \multirow[t]{2}{*}{ Food items } & \multicolumn{2}{|c|}{ Sources of food (Qt) } & \multicolumn{8}{|c|}{ Food expenditure (Qt) } & \multirow{2}{*}{$\begin{array}{l}\text { Net } \\
\text { food } \\
\text { (Qt) }\end{array}$} \\
\hline & Produced & Purchased & Aid & Gift & Total & Loss & Seed & Sales & Transfer & Total & \\
\hline \multicolumn{12}{|l|}{ Staple crops } \\
\hline Barley & 1748.5 & 31.1 & 1.5 & 0.0 & 1781.1 & 103.6 & 263.7 & 84.3 & 6.0 & 459.6 & 1321.6 \\
\hline Wheat & 462.3 & 26.1 & 0.1 & 0.0 & 488.4 & 48.8 & 63.2 & 11.5 & 0.0 & 123.6 & 364.8 \\
\hline Faba bean & 681.9 & 23.9 & 0.0 & 0.0 & 705.8 & 70.6 & 142.8 & 74.7 & 0.0 & 288.1 & 417.6 \\
\hline Pea & 313.5 & 11.5 & 0.0 & 0.0 & 325.0 & 32.5 & 61.8 & 43.9 & 1.5 & 139.7 & 185.3 \\
\hline Lentil & 15.8 & 6.4 & 0.0 & 0.0 & 22.2 & 0.9 & 2.0 & 2.4 & 0.0 & 5.2 & 16.9 \\
\hline Linseed & 12.9 & 0.0 & 0.0 & 0.0 & 12.9 & 1.3 & 0.9 & 4.0 & 0.0 & 6.1 & 6.8 \\
\hline Total & 3234.8 & 98.9 & 1.6 & 0.0 & 3335.4 & 257.7 & 534.4 & 222.7 & 7.5 & 1022.2 & 2313.1 \\
\hline \multicolumn{12}{|l|}{ Vegetables } \\
\hline Potato & 290.3 & 7.9 & 0.0 & 0.0 & 298.2 & 15.0 & 18.0 & 187.0 & 0.0 & 220.0 & 78.2 \\
\hline Leafy vegetables & 6.0 & 14.0 & 0.0 & 0.0 & 20.0 & 0.0 & 0.0 & 1.0 & 0.0 & 1.0 & 19.0 \\
\hline Fruits (apple) & 0.8 & 0.0 & 0.0 & 0.0 & 0.8 & 0.0 & 0.0 & 0.2 & 0.2 & 0.4 & 0.5 \\
\hline Total & 297.1 & 21.9 & 0.0 & 0.0 & 319.0 & 15.0 & 18.0 & 188.2 & 0.2 & 221.4 & 97.7 \\
\hline \multicolumn{12}{|l|}{ Animal product } \\
\hline Meat & 48.11 & 0.04 & 0.0 & 0.0 & 48.1 & 1.9 & 0.0 & 0.0 & 0.0 & 1.9 & 46.2 \\
\hline Egg & 31.3 & 1.2 & 0.0 & 0.0 & 32.4 & 0.0 & 16.5 & 0.0 & 0.0 & 16.5 & 15.9 \\
\hline Milk & 222.5 & 3.5 & 0.0 & 0.0 & 226.0 & 0.0 & 0.0 & 4.1 & 0.0 & 4.1 & 221.9 \\
\hline Butter & 3.8 & 0.0 & 0.0 & 0.0 & 3.8 & 0.0 & 0.0 & 3.3 & 0.0 & 3.3 & 0.5 \\
\hline Honey & 183 & 0.0 & 0.0 & 0.0 & 183.0 & 0.0 & 0.0 & 138 & 0.0 & 138.0 & 45.0 \\
\hline Total & 488.7 & 4.7 & 0.0 & 0.0 & 493.3 & 1.9 & 16.5 & 145.4 & 0.0 & 0.0 & 267.4 \\
\hline
\end{tabular}




\section{Determinants of food consumption}

Different factors such as demographic attributes, topographic terrains, disposable income, and others affect food consumption (Aleme and Lemma, 2015). Linear (OLS) regression was used to identify determinants of household food consumption. The dependent variable is household food energy, which took the value of food in terms of kcal. There was no multicollinearity problem among hypothesized independent variables. Contingency coefficient for discrete variables and variance inflation factor for continuous variables were multicollinearity tests and their values were less than 0.75 and 10.0, respectively. Consequently, all independent variables were entered to the model for analysis. The results of linear regression showed that sex, household size, fertilizer, market distance, and land size were influenced household food consumption significantly (Table 6).

Sex of household head (SEX): The coefficient of sex for household head is positive and significant at $5 \%$. It implies that male-headed households have higher level of calories than female-headed households. Male-headed households increase the food dietary energy by $545 \mathrm{kcal}$ keeping all other variables constant. One probable reason for positive effect of sex on household food consumption is that male-headed households could access to and control over income and other economic resources. In contrast, female-headed households are less likely to practice diversified farm activities. That means male-headed households have less chance of being food anxious than female-headed households. The result is similar with several empirical findings. The sex of a household head being male is significant and has positive relationships with household food energy (Messay, 2010; Mesfin, 2014; Arega, 2012; Aziz et al., 2016). It means that female-headed households are more at risk of food than their counterparts.

Table 6: Result of linear regression for household food energy

\begin{tabular}{|c|c|c|c|c|}
\hline Variables & Coef. & $\begin{array}{l}\text { Std. } \\
\text { Error }\end{array}$ & $\begin{array}{l}\mathrm{t}- \\
\text { value }\end{array}$ & Sig. \\
\hline AGE & -0.70 & 9.14 & -0.08 & 0.939 \\
\hline SEX & $545.18 * *$ & 235.77 & 2.31 & 0.022 \\
\hline HHSIZE & $-715.77 * * *$ & 67.96 & -10.53 & 0.000 \\
\hline EDUC & -107.90 & 95.24 & -1.13 & 0.259 \\
\hline INCOME & 0.01 & 0.02 & 0.31 & 0.760 \\
\hline MANURE & 1.95 & 1.79 & 1.09 & 0.278 \\
\hline LIVES & $117.46^{* * *}$ & 57.12 & 2.06 & 0.041 \\
\hline FERT & $6.92 * * *$ & 1.79 & 3.88 & 0.000 \\
\hline EXTEN & -64.43 & 101.35 & -0.64 & 0.526 \\
\hline LAND & $498.38 * *$ & 207.86 & 2.40 & 0.017 \\
\hline DMKT & $24.24 * * *$ & 7.51 & 3.23 & 0.001 \\
\hline DROAD & -10.62 & 9.48 & -1.12 & 0.264 \\
\hline CREDIT & 67.95 & 227.55 & 0.30 & 0.766 \\
\hline Cons & $3956.44 * * *$ & 606.10 & 6.53 & 0.000 \\
\hline
\end{tabular}

Household size (HHSIZE): Household size has negative relationships with household food consumption and significant at $1 \%$. As household size increases by one member, household food calorie decreases almost by
715.7 kcal. Larger household sizes affect household food availability or food energy adversely. The result of this study agrees with several research findings (Messay, 2010; Mesfin, 2014; Arega, 2012; Aziz et al., 2016). Increasing household size deteriorates household food resources (Bashir et al., 2012). Low food per capita combined with high population growth are serious challenges of household food security, particularly where import capacity is limited (Alexandratos and Bruinsma, 2012). The increment of household size puts pressure on food resources and the share of food among household members will be less.

Livestock holding size (LIVES): The relationship between livestock holding and household food availability is positive and significant at 5\%. As livestock size increases by one TLU, household food calories also increases by 117 , holding other variables constant. The positive correlation of livestock size with household food energy is in line with some other research findings (Messay, 2010; Mesfin, 2014; Arega, 2012; Asmelash, 2014; FAO, 2013).

Inorganic fertilizer (FERT): The relationship between inorganic fertilizer and household food consumption is found to be positive and significant at $1 \%$. The positive relationship indicates that the use of fertilizer increases crop production and productivity per unit area. Household food energy increased almost by seven kcal as a household increases the application of fertilizer by one $\mathrm{kg}$. That means up to the optimum level of fertilizer supply, food increases almost seven kcal per one $\mathrm{kg}$ of fertilizer. Households apply different rate of fertilizer depending on the fertility status of the soil and crop varieties. If a household apply $150 \mathrm{~kg}$ of fertilizer per ha to produce cereal crops on a given land, the food energy can increase about 1000 calories. The positive relationship of this result agrees with the findings of other studies (Messay, 2010; Asmelash, 2014; Temesgen et al., 2016).

Total land size (LAND): The correlation between land size and household food energy is positive and significant at $5 \%$. Land is the source of wealth and has the capacity to reduce risk and bear incomes. Land has an ability to increase capital, production yields, investment and ensure food energy. Keeping other factors constant, household food energy increases by $498 \mathrm{kcal}$ as the total land holding size increases by one ha. The result is in conformity with other findings (Mesfin, 2014; Asmelash, 2014). Nonetheless, the result for positive relationship between land and household food energy is not constantly the same.

Market distance (DMKT): The relationship between market distance and household food energy is not as per the prior expectation. The effect of market distance on dietary energy is positive at $1 \%$ significant level. As market distance increases by one minute of walking distance, household food energy increases by $24 \mathrm{kcal}$. About $60 \%$ of households travel less than the mean distance (27.5 minutes) of the local market. About $93 \%$ of households travel at a distance not more than an hour of walking distance. Despite the relationship between market distance and household food energy is positive, the extent of correlation was weak, i.e., R-value 0.312 or $\mathrm{R}^{2}=0.097$.

The local market and the small town of Gudo Beret are found in the same place. According to personal 
observation and key informant interview, the bases of livelihoods for households who reside near to the town or the local market are mainly non-farm/off-farm activities. The information obtained from key informants is consistent with statistical findings. Informants were requested to disclose why market distance was correlated positively with dietary energy. Households who reside near to the market place could have a possibility of selling crop and livestock products often times compared to those who are living far at a distant. Households who reside near to the town or to the local market may misspend their money for alcohol drinking. With the aim of receiving money, those households are expected to sell farm products for their habits. Proximity to the market facilitates selling of farm products (Rahman and Chima, 2016). Contrary to near residents, households situated relatively far from the local market may hoard crop products for their subsistence food requirements.

Households who reside farther from market centers can diversify crops and livestock for their household consumption. High transport costs in accessing to local market may discourage supply of agricultural products. Although the accessibility of market is essential for marketing, access to information and other advantages, households who reside far away from the local market have better food energy than that of households who reside near to the local market. In the study of Sichoongwe $\boldsymbol{e t}$ al (2014), crop diversifiers are located farther distance from the local market.

\section{CONCLUSIONS AND RECOMMENDATIONS}

Food production and consumption are the two most important functions of food systems. Food and nutrition insecurity is one of the key and persistence challenges in Ethiopia. The study area was degraded higher than the tolerable soil erosion limits that resulted in low capacity of production and productivity. Households produced crops and livestock for home consumption, market demands and other socio-economic obligations. The yield produced in the study area was not adequate to feed the current population. Crops in general and grains in particular have played significant roles for food consumption compared to animal products. From this empirical findings point of view, the local market is one of the significant variables that affected household food energy positively. With regard to food supply, households who reside far from the local market or the local town had better opportunity to access food for home consumption compared to households that reside near to the local market. Despite market proximity facilitates better access to various agricultural and industrial products; households were not wise and could not manage their crop and livestock products. They have inadequate knowledge on food budgeting so that the nearby households to the local market sold and waste more food resources compared to households who reside at remote areas. One of the current themes of the food systems is balancing food production and consumption. The government of Ethiopia should deliberate population policy with the intention that the rising population need to have adequate subsistence. In addition, women empowerment can enable them access to and control over food resources.

\section{Acknowledgements}

The authors would like to thank data collectors and respondent farmers who were willing to provide their time for interviews. The authors would like to thank Africa RISING project, Addis Ababa University and University of Gondar for financial support of part of this research.

\section{REFERENCES}

ADMASU, S. (2017). Productive capacity and economic growth in Ethiopia. CDP Background Paper. PP 34. https://www.un.org/development/desa/dpad/wpcontent/uploads/sites/45/publication/CDP-bp-2017$\underline{\text { 34.pdf }}$

ALEMAYEHU, S., DOROSH, P., \& SINAFIKEH, A. Crop Production in Ethiopia: Regional Patterns and Trends: International Food Policy Research Institute (IFPRI). ESSP II Working Paper No. 0016. 2011. Crop Production in Ethiopia: Regional Patterns and Trends. http://essp.ifpri.info/files/2011/02/ESSP2_WP16_Crop-

Production-in-Ethiopia-Regional-Patterns-and-

Trends.pdf

ALEME, A., \& LEMMA, Z. (2015). Contribution of livestock sector in Ethiopian economy: A review. Advances in life science and technology. 29: 79-90. ISSN 2224-7181 (Paper) ISSN 2225-062X

ALEXANDRATOS, N., \& BRUINSMA, J. (2012). World agriculture towards 2030/2050: the 2012 revision. 2012. ESA Working Paper No. 12-03. FAO: Rome. DOI: https://doi.org/10.4236/oalib.1103427

AREGA B. (2012). Determining Food Security Indicators at Household Level in Drought Prone Areas of the Amhara Region of Ethiopia: The Case of Lay Gaint District. Ethiopian Journal of Environmental Studies and Management; 5(4): 422-434. http://dx.doi.org/10.4314/ejesm.v5i4.11

ASANTE, B. O., VILLANO, R. A., PATRICK, I. W., \& BATTESE, G. E. (2017). Determinants of farm diversification in integrated crop-livestock farming systems in Ghana. Renewable Agriculture and Food System.

DOI: https://doi.org/10.1017/S1742170516000545

AZIZ, B., IQBAL, Z., \& BUTT, Z. (2016).The Extent, Cause and Severity of Household Food Insecurity in Pakistan: Evidence from Micro Data. J. Soc Sci. 10(2):4457.

BADEGE B. (2009). Deforestation and land degradation in the Ethiopian highlands: A strategy for physical recovery. Ethiopian e-journal for research and investment foresight. $1(1), \quad 5-18$. https://www.jstor.org/stable/41931353

BASHIR, M. K., SCHILIZZI, S., \& PANDIT, R. (2012). Livestock and Rural Household Food Security: The Case of Small Farmers of the Punjab, Pakistan, Working Paper 1207, School of Agricultural and Resource Economics, University of Western Australia, Crawley, Australia.

BELAY, D., AZAGE, T., \& HEGDE, B. P. (2012).Smallholder livestock production system in Dandi 
District, Oromia Regional State, Central Ethiopia. Global Veterinaria 8 (5): 472-479, 2012. ISSN 1992-6197

BEWKET, W., RADENY, M., \& MUNGAI, C. (2015). Agricultural adaptation and institutional responses to climate change vulnerability in Ethiopia. CCAFS Working Paper no. 106. CGIAR Research Program on Climate Change, Agriculture and Food Security (CCAFS).

https://ccafs.cgiar.org/publications/.

BURROWS, E, \& KUYPER, E. (2018). Nutritionsensitive extension. Global forum for rural advisory services forum. Switzerland;

CLARO, R. M., LEVY, R. B., BANDONI, D. H., \& MONDINI, L. (2010). Per Capita versus Adult Equivalent Estimates of Calorie Availability in Household Budget Survey. Cad. Saúde Pública, Rio de Janeiro; 26 (11): 21882195. http://producao.usp.br/handle/BDPI/13030

COCHRANE, L., \& O'REGAN D. (2015). Legal Harvest and Illegal Trade: Trends, Challenges and Options in Khat Production in Ethiopia. International Journal of Drug Policy; 30:27-34.

DOI: http://dx.doi.org/10.1016/j.drugpo.2016.02.009

CSA (Central Statistical.Agency) (2011). Agricultural sample survey 2015/16 (2008 E.C). Report on Area Production and Farm Management Practice of Belg Season Crops for Private Peasant Holdings. Statistical Bulletin, 578; Volume V.

CSA (Central Statistical.Agency) (2014). Livestock and Livestock Characteristics (Private Peasant Holdings). Agricultural sample survey 2012/13 (2005 E.C.). Central Statistical Agency, Addis Ababa, Ethiopia.

JALETA, D., MBILINYI, B., MAHOO, H., \& LEMENIH, M. (2016). Eucalyptus expansion as relieving and proactive tree in Ethiopia. J Agric Ecol Res Int; 6(3):1-12. DOI: 10.9734/JAERI/2016/22841

DARNHOFER, I., GIBBON, D., \& DEDIEU, B. (2012). Farming systems research: an approach to inquiry. In: Gibbon D, editor. Farming systems into the 21st century: the new dynamic. Dordrecht: Springer. p: 3-31.

CHANYALEW, D., BERHANU, A., \& MELLOR, J. (2010). Ethiopia's Agricultural Sector Policy and Investment Framework (PIF). In: MoARD (ed.). Addis Ababa, Ethiopia.

DERCON, S., \& HILL, R. V.(2009). Growth from agriculture in Ethiopia. Identifying key constraints.

EHNRI (Ethiopian Health and Nutrition Research Institute). (1998). Food Composition Table for Use in Ethiopia. Part IV.

YESHANEH, E., WAGNER, W., EXNER-KITTRIDGE, M., LEGESSE, D., \& BLÖSCHL, G. (2013). Identifying land use/cover dynamics in the Koga Catchment, Ethiopia, from multi-scale data, and implications for environmental change. ISPRS Int J. Geo-Inf; 2:302-23. DOI: https://doi.org/10.3390/ijgi2020302

FAO (Food and Agricultural Organization). (2008). An Introduction to the Basics of Food Security..

FAO, IFAD, UNICEF, WFP, WHO. (2018). The state of food security and nutrition in the world 2018: Building climate resilience for food security and nutrition. Rome, FAO.
FAO, IFAD, WFP. (2013).The State of Food Insecurity in the World. The Multiple Dimensions of Food Security. Rome, FAO.

FAO. (2017). Nutrition-sensitive agriculture and food systems in practice: Options for intervention.

FDRE. (2018). National nutrition sensitive agriculture strategy. Addis Ababa, Ethiopia.

GODFRAY, H. C. J., BEDDINGTON, R. J., CRUTE, I. R., HADDAD, L., LAWRENCE, D., MUIR, J.F. PRETTY, J.,

ROBINSON, S., THOMAS, S. M., \& TOULMIN, C. (2010). Food Security: The Challenge of Feeding 9 Billion People. Science. 327(812): 812-818. DOI: 10.1126/science. 1185383

GUJARATI, D. N. (2003). Basic Econometrics. Published in Gary Burke.

GUUSH, B., HODDINOT, J., \& KUMAR, N. The impact of Ethiopia's PSNP on the nutritional status of children: 2008-2012. International Food Policy Research Institute. 26. 2017.

HERRERO, M., THORNTON, P. K., NOTENBAERT, A., MSANGI, S., WOOD, S., \& KRUSKA, R. (2012). Drivers of change in crop-livestock systems and their potential impacts on agro-ecosystems services and human wellbeing to 2030. A study commissioned by the CGIAR system wide livestock Program, Addis Ababa.

HURNI, H., BERHE, W. A., CHADHOKAR, P., DANIEL, D., GETE, Z., \& GRUNDER, M. (2016). Soil and Water Conservation in Ethiopia: Guidelines for Development Agents. Second revised edition. Bern, Switzerland: Centre for Development and Environment (CDE). University of Bern, with Bern Open Publishing (BOP). Pp.134.

IFAD. (2010). Integrated crop-livestock farming systems. Livestock thematic papers. Tools for project design.

IFAD. (2013). Smallholders, food security and the environment.

ISRAEL GD. (1992).Sampling the evidence of extension program impact. Program evaluation and organizational development, IS AF, University of Florida.

KEARNEY, J. (2010). Food consumption trends and drivers. Phil. Trans. R. Soc. B. 365. 2793-2807. DOI: http://doi.org/10.1098/rstb.2010.0149

MEKONNEN, K., JOGO, W., BEZABIH, M., MULEMA, A. \& THORNE, P. (2019) Determinants of survival and growth of tree lucerne (Chamaecytisus palmensis) in the crop-livestock farming systems of the Ethiopian highlands. Agroforest Syst 93: 279. DOI: https://doi.org/10.1007/s10457-016-0066-1

KURIA, A., LAMOND, G., PAGELLA, T., GEBREKIRSTOS, A., HADGU, K., \& SINCLAIR, F. (2014). Local knowledge of farmers on opportunities and constraints to sustainable intensification of croplivestock-trees: mixed systems in Lemo Woreda, Southern Nations Nationalities and People Region (SNNPR), Ethiopian highlands. A field study report. 2014. https://cgspace.cgiar.org/bitstream/handle/10568/41669/ Lemo_ARmay.pdf?sequence $=1$

LINIGER, H., MEKDASCHI, S. R., HAUERT, C., \& GURTNER, M. (2011). Sustainable land management in practice: guidelines and best practices for Sub-Saharan Africa: field application. Rome: FAO. 
TAMENE, L. ADIMASSU, Z., ELLISON, J., YAEKOB, T., WOLDEAREGAY, K., MEKONNEN, K., THORNE, P., \& BAO LE, Q. (2017). Mapping soil erosion hotspots and assessing the potential impacts of land management practices in the highlands of Ethiopia. Geomorphology; 292:153-63.

https://doi.org/10.1016/j.geomorph.2017.04.038

MESFIN, W. (2014). Determinants of Households Vulnerability to Food Insecurity in Ethiopia: Econometric Analysis of Rural and Urban Households. Journal of Economics and Sustainable Development.5 (24): 70-79. ISSN (Paper) 2222-1700 ISSN (Online) 2222-2855

MESSAY, M. (2010). Food Security Attainment Role of Urban Agriculture: A Case Study from Adama City. EJBE. 1(1): 68-106.

ASMELASH, M. (2014). Rural household food security status and its determinants: The case of Laelaymychew Woreda, Central Zone of Tigrai, Ethiopia. Journal of Agricultural Extension and Rural Development, 6(5), 162167.

https://doi.org/10.5897/JAERD2013.0555

MORAINE, M., DURU, M., NICHOLAS, P., LETERME, P., \& THEROND, O. (2014). Farming system design for innovative crop-livestock integration in Europe. Animal. 8 (8):1204-17. DOI: https://doi.org/10.1017/S1751731114001189

BIRHANU, M. M. (2015). Systematic Reviews of Prevalence and Associated Factors of Under Five Malnutrition in Ethiopia: Finding the Evidence. International Journal of Nutrition and Food Sciences. 4(4): 459-464.

HAREGEWEYN, N., TSUNEKAWA, A., NYSSEN, J., POESEN, J., TSUBO, M., \& MESHESHA, D. T., SCHÜTT, B. ADGO, E. \& TEGEGNE, F. (2015). Soil erosion and conservation in Ethiopia: a review. Prog Phys Geogr, 39(6):750-74.

DOI: https://doi.org/10.1177\%2F0309133315598725

NPC. (2016). Growth and Transformation Plan II (2015/16-2019/20). Volume I. Main Text. Addis Ababa, Ethiopia.

OLANGO, T. M., TESFAYE, B., CATELlANI, M., \& PE, M. E. (2014). Indigenous Knowledge, use and onfarm management of Enset (Ensete ventricosum (Welw) Cheesman) diversity in Wolaita, Southern Ethiopia. Journal of Ethnobiology and Ethnomedicine 10:1-18. DOI: https://doi.org/10.1186/1746-4269-10-41

RAHMAN, S., \& CHIMA, C. D. (2016). Determinants of Food Crop Diversity and Profitability in Southeastern Nigeria: A Multivariate Tobit Approach. Agriculture 6(2): 1-14. https://doi.org/10.3390/agriculture6020014

ROTA, A., \& SPERANDINI, S. (2010). Integrated croplivestock farming systems. Livestock Thematic Papers Tools for Project Design. International Fund for Agriculture Development (IFAD). Rome. https://fcrn.org.uk/sites/default/files/IFAD_LivestockPap er.pdf

SAHLU, H. (2004). Population, development, and environment in Ethiopia. ECSP report.
SAMBERG, L. H., FISHMAN, L., \& ALLENDOR, F. W. (2013). Population genetic structure in a social landscape: Barley in a traditional Ethiopian agricultural system. Evolutionary Applications; 6:1133-1145. DOI: https://onlinelibrary.wiley.com/doi/full/10.1111/eva.1209 1

SICHOONGWE, K., MAPEMBA, L., NG'ONG'OLA, D., \& TEMBO, G. (2014). The Determinants and Extent of Crop Diversification among Smallholder Farmers. A Case Study of Southern Province, Zambia. Intl Food Policy Res Inst. Working paper No 5. pp. 12.

TADESSE, S. A., \& TAFERE, S., M. (2017). Local People's Knowledge on the Adverse Impacts and their Attitudes towards Growing Eucalyptus Woodlot in Gudo Beret Kebele, Basona Worena District, Ethiopia. Ecological Processes; 6(37): 3-13. https://doi.org/10.1186/s13717-017-0105-5

TEMESGEN, K., JEMA, H., BELAINEH, L., \& GIRMA, M. (2016). Econometric Analysis of Rural Households' Resilience to Food Insecurity in West Shoa, Ethiopia. $J$. Food Secur.; 4(3): 58-67. http://pubs.sciepub.com/jfs/4/3/2

TIGIST, B. (2016). Assessment of surface water resource and irrigation practices in Gudo Beret Kebele, Amhara Region, Ethiopia. Thesis Presented to Addis Ababa University, Ethiopia.

TOLEDO, A., \& BURLINGAME, B. (2006). Biodiversity and nutrition: A common path toward global food security and sustainable development. Journal of Food Composition and Analysis; 19:477-483. DOI: https://doi.org/10.1016/j.jfca.2006.05.001

TONGUL, T., \& HOBSON, M. (2013). Scaling-up an Integrated Watershed Management Approach through Social Protection Program in Ethiopia: The MERET and PSNP Schemes. Dublin Ireland.

WFP (World Food Program). (2014). Comprehensive food security and vulnerability analysis (CFSVA). Ethiopia: Ethiopian central statistical agency.

WHO (World Health Organization) (2004). Food and nutrition needs in emergencies. Guideline. https://www.who.int/nutrition/publications/emergencies/ a83743/en/

WILY, L. A. (2011). The tragedy of public lands: The fate of the commons under global commercial pressure. International Land Coalition. CIRAD. https://www.landcoalition.org/sites/default/files/documen ts/resources/WILY_Commons_web_11.03.11.pdf

WORLD BANK. (2013). Ethiopia's Productive Safety Net Program (PSNP) Integrating Disaster and Climate Risk Management. Case Study.

MEKURIA, W., M, NEGETU, W., \& MEKONNEN, K. (2017). Adoption of improved dairy cows and implications for household food security: Evidence in central highland of Ethiopia. Global Journal of Science Frontier Research: Agriculture and Veterinary 17(3):2938.

YAYNESHET, T.v( 2010). Feed resources availability in Tigray region, Northern Ethiopia, for production of export quality meat and livestock. https://agrilife.org/borlaug/files/2012/03/FeedResources-Availability-in-Tigray-Region-Northern- 
Ethiopia-for-Production-of-Export-Quality-Meat-and-

Livestock..pdf

YITEBITU, M., ZEWDU, E., \& SISAY, N. (2010).

Ethiopian forest resources: Current status and future management options in view of access to carbon finances. https://theredddesk.org/resources/ethiopian-forest-

resources-current-status-and-future-management-optionsview-access-carbon 